\title{
The Role of De Novo Variants in Formation of Human Anorectal Malformations
}

\author{
Gabriel C. Dworschak 1,2,3,*, Iris A. L. M. van Rooij 4,*(D) and Heiko M. Reutter $2,5, *$ (D) \\ 1 Department of Pediatrics, Clinic for Pediatrics, University Hospital Bonn, 53127 Bonn, Germany \\ 2 Institute of Human Genetics, University Hospital Bonn, 53127 Bonn, Germany \\ 3 Institute for Anatomy and Cell Biology, University Hospital Bonn, University of Bonn, 53115 Bonn, Germany \\ 4 Department for Health Evidence, Radboud Institute for Health Sciences, Radboud University Medical \\ Center (Radboudumc), 6525 EZ Nijmegen, The Netherlands \\ 5 Department of Neonatology and Pediatric Intensive Care, University Hospital Erlangen, \\ 91054 Erlangen, Germany \\ * Correspondence: gabriel.dworschak@uni-bonn.de (G.C.D.); Iris.vanRooij@radboudumc.nl (I.A.L.M.v.R.); \\ reutter@uni-bonn.de (H.M.R.); Tel.: +49-228-6885-419 (G.C.D. \& H.M.R.)
}

check for updates

Citation: Dworschak, G.C.; van Rooij, I.A.L.M.; Reutter, H.M. The Role of De Novo Variants in Formation of Human Anorectal Malformations. Genes 2021, 12, 1298. https://doi.org/10.3390/genes 12091298

Academic Editor: Vladimir Korinek

Received: 31 July 2021

Accepted: 19 August 2021

Published: 24 August 2021

Publisher's Note: MDPI stays neutral with regard to jurisdictional claims in published maps and institutional affiliations.

Copyright: (C) 2021 by the authors. Licensee MDPI, Basel, Switzerland. This article is an open access article distributed under the terms and conditions of the Creative Commons Attribution (CC BY) license (https:// creativecommons.org/licenses/by/ $4.0 /)$.
Abstract: Anorectal malformations (ARM) represent a rare birth defect of the hindgut that occur in approximately 1 in 3000 live births. Around 60\% of ARM occur with associated anomalies including defined genetic syndromes and associations with chromosomal aberrations. The etiology of ARM is heterogeneous, with the individual environmental or genetic risk factors remaining unknown for the majority of cases. The occurrence of familial ARM and previous epidemiologic analysis suggest autosomal dominant inheritance in a substantial subset of ARM patients. The implicated mortality and reduced fecundity in patients with ARM would lead to allele loss. However, mutational de novo events among the affected individuals could compensate for the evolutionary pressure. With the implementation of exome sequencing, array-based molecular karyotyping and family-based rare variant analyses, the technologies are available to identify the respective factors. This review discusses the identification of disease-causing variants among individuals with ARM. It highlights the role of mutational de novo events.

Keywords: anorectal malformation (ARM); de novo; heritability; fecundity; copy number variation (CNV); birth defect

\section{Introduction}

Anorectal malformations (ARM) comprise a broad spectrum of birth defects, ranging from mild anal anomalies to complex cloacal malformations. The estimated birth prevalence is 1 in 3000 live births, with a male to female ratio of 1.7 [1-4]. Associated anomalies occur within approximately $60 \%$ of patients, most commonly involving the genitourinary tract, cardiovascular system, central nervous system and the skeletal system [4,5]. ARM may present as a feature of a defined genetic syndrome or in association with chromosomal aberrations [6,7]. In this respect, ARM may present non-syndromic (isolated) or syndromic (non-isolated). According to the case classification guidelines for the National Birth Defects Prevention Study [8], ARM patients with a chromosomal or single gene disorder, a defined clinical syndrome, mental retardation, and/or dysmorphisms have syndromic ARM. The clinical management of ARM is mainly reconstructive surgery and life-long symptomatic treatment (i.e., management of chronic constipation, incontinence, recurrent infections, and psychosocial support).

\section{Established Genetic Factors in the etiology of ARM}

Up to $10 \%$ of syndromic ARM are associated with numeric or structural chromosomal anomalies [5,9]. While for the majority of the remaining syndromic phenotypes that cause ARM remain elusive, about 30 known monogenic syndromes have been described with 
ARM as an associated phenotypic feature. Here, we discuss a selection of genetically defined syndromes with special emphasis on de novo variation (Figure 1).

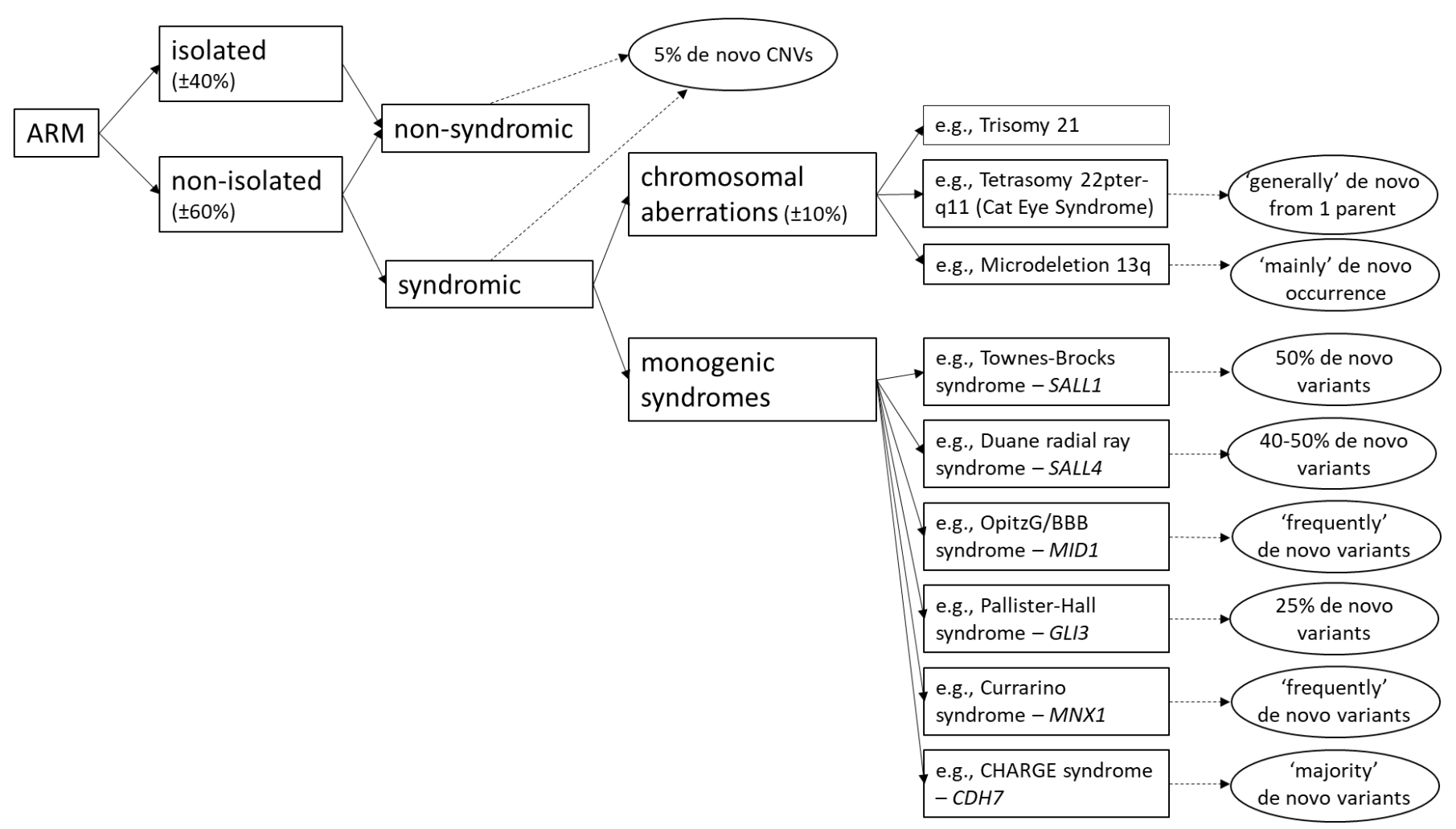

Figure 1. An overview of a selection of relevant genetic causes of ARM and the proportion of de novo variation.

\subsection{Monogenic Syndromes}

\subsubsection{Townes-Brocks Syndrome}

Townes-Brocks syndrome (TBS; OMIM \#107480) is characterized by ARM, thumb anomalies, renal anomalies, cardiac anomalies, dysplastic ears and hearing loss. TBS results from dominant variants in SALL1 that occur in 50\% of patients de novo [10]. Interestingly, pathogenic de novo SALL1 variants most commonly affect the paternally derived chromosome (87.5\%) without an obvious age effect [11]. In 2017, Webb et al. identified a DACT1 variant in a three-generation family with features overlapping with TBS, negative for variants in SALL1 [12]. In a re-sequencing study of 78 patients with ARM, no pathogenic $D A C T 1$ variants were discovered [13] and no additional patient with a DACT1 variant and a phenotype overlapping TBS has been reported since.

\subsubsection{Duane-Radial Ray Syndrome}

The Duane-radial ray syndrome (OMIM \#607323) is an autosomal dominant disorder characterized by upper limb, ocular, and renal anomalies caused by variants in SALL4. Less common features comprise sensorineural hearing loss and gastrointestinal anomalies, such as ARM. Pathogenic variants in SALL4 occur in $40 \%-50 \%$ de novo [14].

\subsubsection{Opitz G/BBB Syndrome}

The X-linked recessive Opitz G/BBB syndrome (OMIM \#300000) is characterized by laryngotracheoesophageal abnormalities, hypospadias, hypertelorism and less commonly ARM, cardiac anomalies and syndactyly. Hemizygous pathogenic variants in MID1 have been identified as the underlying genetic cause. Despite the Opitz G/BBB syndrome following an X-linked-recessive heritability, de novo events have been frequently reported [15-17]. 


\subsubsection{Pallister-Hall Syndrome}

Pallister-Hall syndrome (OMIM \#146510) is characterized by hypothalamic hamartoma, polydactyly, bifid epiglottis, ARM, and genitourinary tract anomalies. Heterozygous variants in GLI3 have been described as causative and about $25 \%$ of patients have a de novo pathogenic variant $[18,19]$. Interestingly, patients with a de novo GLI3 pathogenic variant are often more severely affected than patients with a family history of Pallister-Hall syndrome [20].

\subsubsection{Currarino Syndrome}

Currarino syndrome (CS; OMIM \#176450) is characterized by the triad of a presacral mass, sacral anomalies and ARM [21]. Heterozygous variants in MNX1 have been identified in $92 \%$ of familial and $32 \%$ of sporadic cases [22]. The fraction of de novo MNX1 variants has not been systematically studied, but there are frequent reports of de novo occurrence [23-26]. Since CS presents with variable expressivity and pathogenic variants may have a reduced penetrance, it is not surprising that completely asymptomatic individuals with pathogenic MNX1 variants have been reported [27]. However, even if a patient appears to represent a sporadic case, screening of the parents for features of CS and genetic testing of the parents in the case of identification of a MNX1 variant in the patient is recommended [22].

\subsubsection{CHARGE Syndrome}

The CHARGE syndrome (\#214800) comprises coloboma, heart defect, choanal atresia, growth retardation, developmental delay, genital hypoplasia, ear anomalies (including deafness) and ARM. Heterozygous variants in CHD7 have been identified as causative. Pathogenic variants in $\mathrm{CHD7}$ occur in the majority of cases de novo [28] and affect predominantly the paternal allele [29]. About $70 \%$ of these variants represent nonsense or frameshift variants [30].

\subsection{Chromosomal Anomalies}

\subsubsection{Trisomy 21}

Between $2 \%$ and $5 \%$ of patients with ARM have trisomy 21 [5,31] and vice versa about $0.9 \%$ of patients with Down syndrome present with ARM [32]. Over $95 \%$ of patients with Down syndrome and ARM have a rare form, i.e., imperforate anus without fistula [33]. The majority of patients with trisomy 21 have three free copies of chromosome $21(95 \%)$; in the remaining patients, one copy is translocated to another acrocentric chromosome, most commonly chromosome 14 or 21 [34].

\subsubsection{Cat Eye Syndrome}

Cat eye syndrome (OMIM \#115470) comprises ocular colobomas, preauricular abnormalities, ARM and mild to moderate intellectual disability. Cat eye syndrome is caused by a partial tetrasomy (i.e., four copies) of the region spanning the p-arm and a part of 22q11 [35]. The extra material is usually in the form of a small supernumerary chromosome, frequently has two centromeres, is bisatellited, and represents an inv dup(22)(q11). The supernumerary chromosome 22 generally originates de novo from one of the parents [36].

\subsubsection{Microdeletion 13q}

The phenotypic spectrum of $13 q$ deletions is broad and comprises intellectual disability, growth retardation, renal, heart and brain malformation, ARM and other gastrointestinal abnormalities, genital abnormalities and limb malformation, especially absent or hypoplastic thumbs, and characteristic craniofacial dysmorphisms [37]. Interestingly, certain anomalies have been mapped to specific deleted regions [38]. The critical region for ARM has been described as $11 \mathrm{Mb}$, flanked by q33.1 (103 Mb) and q34 (qter) [38,39] and later refined to 13q33.3-qter [40]. While the ratio of de novo occurrence has not been 
systematically assessed, the reported series of patients suggest a de novo occurrence as the main cause for partial 13q deletions $[40,41]$.

\section{Candidate Genes and Copy Number Variants}

The aforementioned syndromes with identified genetic causes, the occurrence of familial ARM and the finding of ARM in knockout mouse models strongly indicate a genetic contribution in the etiology of ARM. However, by the investigation of genes known to cause syndromes that share ARM as one of the features, only a small proportion of patients are molecularly solved [42]. Therefore, it appeared reasonable to conduct systematic genetic studies in order to explain the missing heritability.

Several studies have systematically employed array-based molecular karyotyping in order to investigate the genetic factors underlying ARM. In a cohort of 224 non-syndromic and syndromic ARM patients [40,43-48], 12 patients (5\%) were identified with a pathogenic de novo CNV. Furthermore, the authors detected potentially pathogenic CNVs in six patients with unclear segregation since the respective parent(s) were not available for testing. Among the de novo CNVs two deletions comprised chromosomal region 13q33 [40]. Furthermore, four CNVs comprising chromosomal region 22q11.2 were identified. Here, one deletion and one duplication of chromosomal region 22q11.21 were confirmed to be de novo [43,46], and for two deletions only one parent was available for segregation testing $[46,48]$. Among these CNVs there were regions that have been repeatedly associated with ARM, such as chromosomal regions 22q11.21 and 13q33.

Another study investigating 363 ARM patients showed a 1.3-fold significant excess of rare CNVs in patients compared to controls [49]. In total, twelve chromosomal aberrations and 114 rare CNVs were detected in patients. However, these data are not comparable with the aforementioned studies, since the filtering of these variants was performed regardless of the inheritance pattern and segregation status.

A study of 123 patients with VACTERL-association (OMIM\%192350) has applied a targeted re-sequencing approach of ciliary candidate genes as well as disease-associated genes. Heterozygous variants in FOXF1 were previously reported in patients with alveolar capillary dysplasia and misalignment of the pulmonary veins [50]. The authors identified a de novo variant in FOXF1 (p.Gly220Cys) in a patient with ARM, left-sided renal agenesis, and glandular hypospadias [51].

Another candidate re-sequencing study of 211 VACTERL and 204 ARM patients included 30 candidate genes that were described previously in relation to VACTERL features, either in animal models or in individual patients [42]. However, the authors did not identify loss-of-function variants in the candidate genes, indicating genetic heterogeneity in the etiology of ARM.

\section{Epidemiological Aspects-A De Novo Paradigm}

Although ARM is usually sporadic, the occurrence of familial ARM affecting multiple generations suggested autosomal dominant inheritance in, at least, a subset of families [52]. In an epidemiological study in a cohort of 1606 ARM patients Falcone et al. reported an additional family member with ARM in $1.4 \%$ of patients [53]. Later, in a study with 327 ARM patients the risk of recurrence between siblings was calculated, with $1 \%$ supporting the figure from Falcone et al. [54]. However, the same study suggested a recurrence risk of ARM of approximately one in two live births (62\%) for parent-offspring transmission. This finding supports the hypothesis of autosomal dominant inheritance for a subset of ARM patients.

Not even five decades ago, ARM have been associated with a significant mortality and morbidity. Especially the implicated mortality and the reduced fecundity in patients with ARM lead to allele loss. Although the evolutionary pressure would eliminate such deleterious alleles, the prevalence of ARM has been relatively stable between 1980 and 2019 according to data of the European Surveillance of Congenital Malformations (EUROCAT) network (www.eurocat-network.eu, accessed on 28 July 2021) [55]. Since the human per- 
generation mutation rate is exceptionally high compared to other species, with an average newborn acquiring a total of 50 to 100 de novo variants [56], these variants may have severe phenotypic effects when they affect functionally important bases in the genome. The de novo occurrence of deleterious variants may explain a stable prevalence of disease in the human population. This paradigm is especially appropriate when the mutational target is large and includes many genes. Similar mechanisms have been shown for other disorders that compromise individual fecundity, such as mental retardation [57].

Due to the improvement of delicate surgical techniques, such as the definitive repair of $\mathrm{ARM}$, sexual function can be preserved more often, resulting in more offspring of patients with ARM. This would lead to a higher burden of deleterious variants and ultimately lead to an increase in the prevalence of ARM. However, it remains to be seen how these factors will develop in the future.

\section{Conclusions and Outlook}

Several lines of evidence show different genetic factors to be involved in the development of ARM. These factors are heterogeneous and include chromosomal aberrations, copy number variants and single nucleotide variants. De novo variants contribute substantially to the epidemiologic disease burden. Similar to what has been shown for other genetic conditions associated with reduced fecundity, de novo variants may compensate for allele loss in patients with ARM.

Exploration and characterization of the complete genome will ultimately identify regulatory genetic elements that might also contribute to the formation of ARM. The identification of these de novo variations within these regulatory elements might complement the missing heritability among cases with ARM.

Author Contributions: G.C.D., I.A.L.M.v.R. and H.M.R., investigation writing, original draft writing, and review and editing. All authors have read and agreed to the published version of the manuscript.

Funding: G.C.D. is supported by BONFOR stipends O-120.0001. H.M.R. is supported by a grant from the German Research Foundation (Deutsche Forschungsgemeinschaft, DFG) RE1723/2-1.

Institutional Review Board Statement: Not applicable.

Informed Consent Statement: Not applicable.

Data Availability Statement: Not applicable.

Acknowledgments: We thank all affected individuals and their families for their participation in the respective studies. Furthermore, we thank the German self-help organization SoMA e.V. for their continuous support.

Conflicts of Interest: The authors declare no conflict of interest. The funders had no role in the design of the study; in the collection, analyses, or interpretation of data; in the writing of the manuscript, or in the decision to publish the results.

\section{References}

1. Cuschieri, A. Descriptive epidemiology of isolated anal anomalies: A survey of 4.6 million births in Europe. Am. J. Med. Genet. 2001, 103, 207-215. [CrossRef]

2. Jenetzky, E. Prevalence estimation of anorectal malformations using German diagnosis related groups system. Pediatr. Surg. Int. 2007, 23, 1161-1165. [CrossRef]

3. Levitt, M.A.; Peña, A. Anorectal malformations. Orphanet J. Rare Dis. 2007, 2, 33. [CrossRef] [PubMed]

4. Stoll, C.; Alembik, Y.; Dott, B.; Roth, M.P. Associated malformations in patients with anorectal anomalies. Eur. J. Med. Genet. 2007, 50, 281-290. [CrossRef] [PubMed]

5. Cuschieri, A. Anorectal anomalies associated with or as part of other anomalies. Am. J. Med. Genet. 2002, 110, 122-130. [CrossRef] [PubMed]

6. Marcelis, C.; de Blaauw, I.; Brunner, H. Chromosomal anomalies in the etiology of anorectal malformations: A review. Am. J. Med. Genet. Part A 2011, 155, 2692-2704. [CrossRef]

7. Martuciello, G. Genetics of anorectal malformations. In Anorectal Malformations in Children; Holschneider, H., Hutson, J., Eds.; Springer: Heidelberg, Germany, 2006; pp. 31-48. 
8. Rasmussen, S.A.; Olney, R.S.; Holmes, L.B.; Lin, A.E.; Keppler-Noreuil, K.M.; Moore, C.A. Guidelines for case classification for the National Birth Defects Prevention Study. Birth Defects Res. Part A Clin. Mol. Teratol. 2003, 67, 193-201. [CrossRef]

9. Moore, S.W. Associations of anorectal malformations and related syndromes. Pediatr. Surg. Int. 2013, 29, 665-676. [CrossRef]

10. Kohlhase, J. Townes-brocks syndrome. In GeneReviews ${ }^{\circledR}$; University of Washington: Seattle, WA, USA, 2016. Available online: https: / / www.ncbi.nlm.nih.gov / books/NBK1445/ (accessed on 28 July 2021).

11. Böhm, J.; Munk-Schulenburg, S.; Felscher, S.; Kohlhase, J. SALL1 mutations in sporadic Townes-Brocks syndrome are of predominantly paternal origin without obvious paternal age effect. Am. J. Med. Genet. Part A 2006, 140, 1904-1908. [CrossRef]

12. Webb, B.D.; Metikala, S.; Wheeler, P.G.; Sherpa, M.D.; Houten, S.M.; Horb, M.E.; Schadt, E.E. Heterozygous pathogenic variant in DACT1 causes an autosomal-dominant syndrome with features overlapping townes-brocks syndrome. Hum. Mutat. 2017, 38, 373-377. [CrossRef]

13. Draaken, M.; Prins, W.; Zeidler, C.; Hilger, A.; Mughal, S.S.; Latus, J.; Boemers, T.M.; Schmidt, D.; Schmiedeke, E.; Spychalski, N.; et al. Involvement of the WNT and FGF signaling pathways in non-isolated anorectal malformations: Sequencing analysis of WNT3A, WNT5A, WNT11, DACT1, FGF10, FGFR2 and the T gene. Int. J. Mol. Med. 2012, 30, 1459-1464. [CrossRef]

14. Kohlhase, J. SALL4-related disorders. In GeneReviews ${ }^{\circledR}$; University of Washington: Seattle, WA, USA, 2015. Available online: https: / / www.ncbi.nlm.nih.gov / books/NBK1373/ (accessed on 28 July 2021).

15. Pinson, L.; Augé, J.; Audollent, S.; Mattéi, G.; Etchevers, H.; Gigarel, N.; Razavi, F.; Lacombe, D.; Odent, S.; Le Merrer, M.; et al. Embryonic expression of the human MID1 gene and its mutations in Opitz syndrome. J. Med. Genet. 2004, 41, 381-386. [CrossRef]

16. Ferrentino, R.; Bassi, M.T.; Chitayat, D.; Tabolacci, E.; Meroni, G. MID1 mutation screening in a large cohort of Opitz G/BBB syndrome patients: Twenty-nine novel mutations identified. Hum. Mutat. 2007, 28, 206-207. [CrossRef]

17. Fontanella, B.; Russolillo, G.; Meroni, G. MID1 mutations in patients with X-linked Opitz G/BBB syndrome. Hum. Mutat. 2008, 29, 584-594. [CrossRef]

18. Johnston, J.J.; Olivos-Glander, I.; Killoran, C.; Elson, E.; Turner, J.T.; Peters, K.F.; Abbott, M.H.; Aughton, D.J.; Aylsworth, A.S.; Bamshad, M.J.; et al. Molecular and clinical analyses of Greig cephalopolysyndactyly and pallister-hall syndromes: Robust phenotype prediction from the type and position of GLI3 mutations. Am. J. Hum. Genet. 2005, 76, 609-622. [CrossRef]

19. Johnston, J.J.; Sapp, J.C.; Turner, J.T.; Amor, D.; Aftimos, S.; Aleck, K.A.; Bocian, M.; Bodurtha, J.N.; Cox, G.F.; Curry, C.J.; et al. Molecular analysis expands the spectrum of phenotypes associated with GLI3 mutations. Hum. Mutat. 2010, 31, 1142-1154. [CrossRef] [PubMed]

20. Biesecker, L.G. Pallister-hall syndrome. J. Pediatr. Neurosci. 2017, 12, 276-279. [CrossRef] [PubMed]

21. Currarino, G.; Coln, D.; Votteler, T. Triad of anorectal, sacral, and presacral anomalies. Am. J. Roentgenol. 1981, 137, 395-398. [CrossRef] [PubMed]

22. Dworschak, G.C.; Reutter, H.M.; Ludwig, M. Currarino syndrome: A comprehensive genetic review of a rare congenital disorder. Orphanet J. Rare Dis. 2021, 16, 167. [CrossRef]

23. Ross, A.J.; Ruiz-Perez, V.; Wang, Y.; Hagan, D.M.; Scherer, S.; Lynch, S.A.; Lindsay, S.; Custard, E.; Belloni, E.; Wilson, D.I.; et al. A homeobox gene, HLXB9, is the major locus for dominantly inherited sacral agenesis. Nat. Genet. 1998, 20, 358-361. [CrossRef]

24. Zu, S.; Winberg, J.; Arnberg, F.; Palmer, G.; Svensson, P.J.; Wester, T.; Nordenskjöld, A. Mutation analysis of the motor neuron and pancreas homeobox 1 (MNX1, former HLXB9) gene in Swedish patients with Currarino syndrome. J. Pediatr. Surg. 2011, 46, 1390-1395. [CrossRef]

25. Han, L.; Zhang, Z.; Wang, H.; Song, H.; Gao, Q.; Yan, Y.; Tao, R.; Xiao, P.; Li, L.; Jiang, Q.; et al. Novel MNX1 mutations and genotype-phenotype analysis of patients with Currarino syndrome. Orphanet J. Rare Dis. 2020, 15, 155. [CrossRef]

26. Köchling, J.; Karbasiyan, M.; Reis, A. Spectrum of mutations and genotype-Phenotype analysis in Currarino syndrome. Eur. J. Hum. Genet. 2001, 9, 599-605. [CrossRef] [PubMed]

27. Lynch, S.A.; Wang, Y.; Strachan, T.; Burn, J.; Lindsay, S. Autosomal dominant sacral agenesis: Currarino syndrome. J. Med. Genet. 2000, 37, 561-566. [CrossRef] [PubMed]

28. van Ravenswaaij-Arts, C.M.; Hefner, M.; Blake, K.; Martin, D.M. CHD7 Disorder; University of Washington: Seattle, WA, USA, 1993.

29. Pauli, S.; von Velsen, N.; Burfeind, P.; Steckel, M.; Mänz, J.; Buchholz, A.; Borozdin, W.; Kohlhase, J. CHD7 mutations causing CHARGE syndrome are predominantly of paternal origin. Clin. Genet. 2012, 81, 234-239. [CrossRef] [PubMed]

30. Zentner, G.E.; Layman, W.S.; Martin, D.M.; Scacheri, P.C. Molecular and phenotypic aspects of CHD7 mutation in CHARGE syndrome. Am. J. Med. Genet. Part A 2010, 152A, 674-686. [CrossRef] [PubMed]

31. Cho, S.; Moore, S.P.; Fangman, T. One hundred three consecutive patients with anorectal malformations and their associated anomalies. Arch. Pediatr. Adolesc. Med. 2001, 155, 587-591. [CrossRef]

32. Källén, B.; Mastroiacovo, P.; Robert, E. Major congenital malformations in Down syndrome. Am. J. Med. Genet. 1996, 65, 160-166. [CrossRef]

33. Endo, M.; Hayashi, A.; Ishihara, M.; Maie, M.; Nagasaki, A.; Nishi, T.; Saeki, M. Analysis of 1992 patients with anorectal malformations over the past two decades in Japan. J. Pediatr. Surg. 1999, 34, 435-441. [CrossRef]

34. Thuline, H.C.; Pueschel, S.M. Cytogenetics in down syndrome. In Down Syndrome: Advances in Biomedicine and the Behavioral Sciences; Pueschel, S.M., Rynders, J.E., Eds.; Ware Press: Cambridge, UK, 1982; p. 133. 
35. Schinzel, A.; Schmid, W.; Auf der Maur, P.; Moser, H.; Degenhardt, K.H.; Geisler, M.; Grubisic, A. Incomplete trisomy 22. I. Familial 11/22 translocation with 3:1 meiotic disjunction. Delineation of a common clinical picture and report of nine new cases from six families. Hum. Genet. 1981, 56, 249-262. [CrossRef]

36. Rosias, P.P.R.; Sijstermans, J.M.J.; Theunissen, P.M.V.M.; Pulles-Heintzberger, C.F.M.; De Die-Smulders, C.E.M.; Engelen, J.J.M.; Van der Meer, S.B. Phenotypic variability of the cat eye syndrome. Case report and review of the literature. Genet. Couns. 2001, 12, 273-282.

37. Quélin, C.; Bendavid, C.; Dubourg, C.; de la Rochebrochard, C.; Lucas, J.; Henry, C.; Jaillard, S.; Loget, P.; Loeuillet, L.; Lacombe, D.; et al. Twelve new patients with 13q deletion syndrome: Genotype-phenotype analyses in progress. Eur. J. Med. Genet. 2009, 52, 41-46. [CrossRef] [PubMed]

38. Kirchhoff, M.; Bisgaard, A.M.; Stoeva, R.; Dimitrov, B.; Gillessen-Kaesbach, G.; Fryns, J.P.; Rose, H.; Grozdanova, L.; Ivanov, I.; Keymolen, K.; et al. Phenotype and 244k array-cgh characterization of chromosome 13q deletions: An update of the phenotypic map of 13q21.1-qter. Am. J. Med. Genet. Part A 2009, 149, 894-905. [CrossRef] [PubMed]

39. Garcia, N.M.; Allgood, J.; Santos, L.J.; Lonergan, D.; Batanian, J.R.; Dravis, C.; Henkemeyer, M.; Bartsch, O.; Schultz, R.A.; Zinn, A.R.; et al. Deletion mapping of critical region for hypospadias, penoscrotal transposition and imperforate anus on human chromosome 13. J. Pediatr. Urol. 2006, 2, 233-242. [CrossRef] [PubMed]

40. Dworschak, G.C.; Draaken, M.; Marcelis, C.; de Blaauw, I.; Pfundt, R.; van Rooij, I.A.L.M.; Bartels, E.; Hilger, A.; Jenetzky, E.; Schmiedeke, E.; et al. De novo 13q deletions in two patients with mild anorectal malformations as part of VATER/VACTERL and VATER/VACTERL-like association and analysis of EFNB2 in patients with anorectal malformations. Am. J. Med. Genet. Part A 2013, 161, 3035-3041. [CrossRef] [PubMed]

41. Ballarati, L.; Rossi, E.; Bonati, M.T.; Gimelli, S.; Maraschio, P.; Finelli, P.; Giglio, S.; Lapi, E.; Bedeschi, M.F.; Guerneri, S.; et al. $13 \mathrm{q}$ Deletion and central nervous system anomalies: Further insights from karyotype-phenotype analyses of 14 patients. J. Med. Genet. 2006, 44, e60. [CrossRef]

42. van de Putte, R.; Dworschak, G.C.; Brosens, E.; Reutter, H.M.; Marcelis, C.L.M.; Acuna-Hidalgo, R.; Kurtas, N.E.; Steehouwer, M.; Dunwoodie, S.L.; Schmiedeke, E.; et al. A genetics-first approach revealed monogenic disorders in patients with ARM and VACTERL anomalies. Front. Pediatr. 2020, 8, 310. [CrossRef]

43. Schramm, C.; Draaken, M.; Bartels, E.; Boemers, T.M.; Aretz, S.; Brockschmidt, F.F.; Nöthen, M.M.; Ludwig, M.; Reutter, H. De novo microduplication at 22q11.21 in a patient with VACTERL association. Eur. J. Med. Genet. 2011, 54, 9-13. [CrossRef]

44. Schramm, C.; Draaken, M.; Bartels, E.; Boemers, T.M.; Schmiedeke, E.; Grasshoff-Derr, S.; Märzheuser, S.; Hosie, S.; Holland-Cunz, S.; Baudisch, F.; et al. De novo duplication of 18p11.21-18q12.1 in a female with anorectal malformation. Am. J. Med. Genet. Part A 2011, 155, 445-449. [CrossRef]

45. Hilger, A.; Schramm, C.; Pennimpede, T.; Wittler, L.; Dworschak, G.C.; Bartels, E.; Engels, H.; Zink, A.M.; Degenhardt, F.; Müller, A.M.; et al. De novo microduplications at 1q41, 2q37.3, and 8q24.3 in patients with VATER/VACTERL association. Eur. J. Hum. Genet. 2013, 21, 1377-1382. [CrossRef]

46. Dworschak, G.C.; Draaken, M.; Hilger, A.C.; Schramm, C.; Bartels, E.; Schmiedeke, E.; Grasshoff-Derr, S.; Märzheuser, S.; Holland-Cunz, S.; Lacher, M.; et al. Genome-wide mapping of copy number variations in patients with both anorectal malformations and central nervous system abnormalities. Birth Defects Res. Part A Clin. Mol. Teratol. 2015, 103, 235-242. [CrossRef]

47. Dworschak, G.C.; Crétolle, C.; Hilger, A.; Engels, H.; Korsch, E.; Reutter, H.; Ludwig, M. Comprehensive review of the duplication $3 q$ syndrome and report of a patient with Currarino syndrome and de novo duplication 3q26.32-q27.2. Clin. Genet. 2017, 91, 661-671. [CrossRef] [PubMed]

48. Zhang, R.; Marsch, F.; Kause, F.; Degenhardt, F.; Schmiedeke, E.; Märzheuser, S.; Hoppe, B.; Bachour, H.; Boemers, T.M.; Schäfer, M.; et al. Array-based molecular karyotyping in 115 VATER/VACTERL and VATER/VACTERL-like patients identifies disease-causing copy number variations. Birth Defects Res. 2017, 109, 1063-1069. [CrossRef] [PubMed]

49. Wong, E.H.M.; Cui, L.; Ng, C.L.; Tang, C.S.M.; Liu, X.L.; So, M.T.; Yip, B.H.K.; Cheng, G.; Zhang, R.; Tang, W.K.; et al. Genomewide copy number variation study in anorectal malformations. Hum. Mol. Genet. 2013, 22, 621-631. [CrossRef] [PubMed]

50. Stankiewicz, P.; Sen, P.; Bhatt, S.S.; Storer, M.; Xia, Z.; Bejjani, B.A.; Ou, Z.; Wiszniewska, J.; Driscoll, D.J.; Bolivar, J.; et al. Genomic and genic deletions of the FOX gene cluster on 16q24.1 and inactivating mutations of FOXF1 cause alveolar capillary dysplasia and other malformations. Am. J. Hum. Genet. 2009, 84, 780-791. [CrossRef]

51. Hilger, A.C.; Halbritter, J.; Pennimpede, T.; van der Ven, A.; Sarma, G.; Braun, D.A.; Porath, J.D.; Kohl, S.; Hwang, D.Y.; Dworschak, G.C.; et al. Targeted resequencing of 29 candidate genes and mouse expression studies implicate ZIC3 and FOXF1 in human VATER/VACTERL association. Hum. Mutat. 2015, 36, 1150-1154. [CrossRef]

52. Schramm, C.; Draaken, M.; Tewes, G.; Bartels, E.; Schmiedeke, E.; Märzheuser, S.; Grasshoff-Derr, S.; Hosie, S.; Holland-Cunz, S.; Priebe, L.; et al. Autosomal-dominant non-syndromic anal atresia: Sequencing of candidate genes, array-based molecular karyotyping, and review of the literature. Eur. J. Pediatr. 2011, 170, 741-746. [CrossRef]

53. Falcone, R.A.; Levitt, M.A.; Peña, A.; Bates, M. Increased heritability of certain types of anorectal malformations. J. Pediatr. Surg. 2007, 42, 124-128. [CrossRef]

54. Dworschak, G.C.; Zwink, N.; Schmiedeke, E.; Mortazawi, K.; Märzheuser, S.; Reinshagen, K.; Leonhardt, J.; Gómez, B.; Volk, P.; Rißmann, A.; et al. Epidemiologic analysis of families with isolated anorectal malformations suggests high prevalence of autosomal dominant inheritance. Orphanet J. Rare Dis. 2017, 12, 180. [CrossRef] 
55. EUROCAT. Prevalence Charts and Tables. Available online: https://eu-rd-platform.jrc.ec.europa.eu/eurocat/eurocat-data/ prevalence_en (accessed on 27 July 2021).

56. Lynch, M. Rate, molecular spectrum, and consequences of human mutation. Proc. Natl. Acad. Sci. USA 2010, 107, 961-968. [CrossRef]

57. Vissers, L.E.L.M.; De Ligt, J.; Gilissen, C.; Janssen, I.; Steehouwer, M.; De Vries, P.; Van Lier, B.; Arts, P.; Wieskamp, N.; Del Rosario, M.; et al. A de novo paradigm for mental retardation. Nat. Genet. 2010, 42, 1109-1112. [CrossRef] [PubMed] 